\title{
Determination of the Antineoplastic Activivity of Berberine Isolated from Tinospora cordifolia in Swiss Albino Mice Transplanted with Ehrlich Ascites Carcinoma
}

\author{
Ganesh Chandra Jagetia ${ }^{1 *}$ and SK Rao ${ }^{2}$ \\ ${ }^{1}$ Department of Zoology, Mizoram University, India \\ ${ }^{2}$ Department of Pharmacognosy, C U Shah College of Pharmacy \& Research, India
}

Submission: May 04, 2017; Published: June 30, 2017

*Corresponding author: Ganesh Chandra Jagetia, Department of Zoology, Mizoram University, Aizwal-796 004, India, Tel: 91-389-2330724/2330227; Email: gc.jagetia@gmail.com

\begin{abstract}
Natural products have attracted the attention of humans for healthcare since time immemorial. The anticancer activity of berberine chloride (BCL), an alkaloid isolated from the dichloromethane extract of Tinospora cordifolia, was studied in mice transplanted with Ehrlich ascites carcinoma (EAC) by injecting $10 \mathrm{mg} / \mathrm{kg}$ BCL on 1, 3, 6, 9, 12 or 15 days, (stage I, II, III, IV, V and VI) after EAC inoculation. The data analysis revealed that maximum tumor free survivors (58.3\%) at 30 days were observed in mice receiving BCL on second day of tumorization. The administration of BCL on day 3 and 4 after tumor inoculation also increased the tumor free survivors at 30 days. Despite this increase in survival, no long term survivors ( $>60$ days) could be reported at any of the stages evaluated. The BCL treatment was more effective than cyclophosphamide, the positive control, which was effective only at stage I and II, however, the number of tumor free survivors on day 30 was lesser than the BCL treatment. The analysis of lipid peroxidation and GSH contents in EAC cells showed a time dependent depletion in the GSH activity up to $9 \mathrm{~h}$ post-treatment and a marginal elevation thereafter. This depletion in GSH was accompanied by a drastic elevation in lipid peroxidation with a maximum rise at $9 \mathrm{~h}$ post-treatment and a gradual decline thereafter. Our study demonstrates that BCL treatment caused tumor regression and increased tumor free survival by reducing the GSH concentration and increasing the lipid peroxidation.
\end{abstract}

Keywords: Mice; Ehrlich ascites carcinoma; Survival; Glutathione; Lipid peroxidation

\section{Introduction}

The chemotherapy is one of the important modalities to treat cancer and it is especially helpful in the advance stages of cancer treatment. Chemotherapy is either used alone or in conjunction with radiation and/or surgery to treat difficult neoplasia. The term chemotherapy was coined by Paul Ehrlich, in 1907 against the drug/s used to treat infection, however now it is synonymous with the drugs that are used for cancer treatment [1,2]. It is well known that most of the chemotherapeutic drugs act on proliferating cancer cells by triggering DNA damage in these cells and this not only results in chemotherapy resistance after repeated uses of these agents but also leads to the development of second malignancies in the fortunate survivors [3-5]. Despite the availability of several treatment modalities in modern medicine, the mortality rate after cancer treatment have not come down and remains at the level of 1950, especially for solid tumors [6]. Further cancer chemotherapy is associated with severe side effect in the various other organs that are devoid of cancer [7-9]. This indicates the need of alternative drugs which are highly effective and less or negligibly toxic to normal cells.

Plants and natural products have played a crucial role in the human healthcare and the herbal preparations and natural products have been used to treat cancer since time immemorial [10]. Ayurveda, the Indian system of medicine mainly uses plant based drugs or formulations to treat different human health disorders including cancer. The plants and natural products still continue to play important role as complementary and alternative medicine apart from the standard modern chemotherapy in the management of cancer. Medicines derived from plants have played a pivotal role in healthcare of ancient cultures and also continue to play a significant role even in modern times [11]. It is also well known that most effective modern chemotherapeutic drugs like vinca alkaloids, epipodophyllotoxins, camaptothecins taxanes, bleomycins and doxorubicin have been derived from plants/ natural products before their actual chemical synthesis began 
[12]. The surveys in US indicate that one in three Americans uses dietary supplements daily for their healthcare and in cancer patients visiting different cancer centers for treatment, the usage is as high as $50 \%[13,14]$. The herbal medicines are more popular in general public due to the belief that the phytoceuticals will provide some measure of benefit over and above modern allopathic medical approaches. They are also considered nontoxic or less toxic than the synthetic molecules [15].

Berberine is an isoquinoline alkaloid and is synthesized by several plants including Tinospora cordifolia. It has been reported to possess diverse pharamolcogical actions including antibacterial, antifungal, anticholesterolase, antidiarrheal, antiinflammatory, antioxidant, hepatoprotective, antiarrhythmic, and antihypertensive activities [16-22]. Preclinical studies have reported the chemopreventive and antineoplastic activities of berberine in vivo and in vitro earlier [23-25]. Berberine is active against diabetes, coronary artery diseases, fatty liver disease, diarrhea, gastroenteritis, obesity, hyperlipidemia, hypertension, Alzheimer's disease, metabolic syndrome, and polycystic ovary $[26,27]$. Clinically berberine has been reported to improve the cardiac performance in patients presenting heart failure and it exerted a direct depressive action on myocardial vasculature and smooth musculature [28]. An improvement in left ventricular ejection fraction and ventricular premature complexes has been reported in the patients with chronic congestive heart failure after administration of 1.2 to $2 \mathrm{~g}$ of berberine daily [29]. Clinical studies have shown that berberine treatment was effective in type 2 diabetes in human subjects [30-32]. Berberine administration has been clinically very effective in the treatment of dyslipidemia, dementia, non-fatty liver disease, hyperlipidemia, and ocular Behcet's disease [33-38]. Recent studies from our laboratory have shown that berberine is cytotoxic to HeLa cells and the cytotoxic effect may be due to triggering of molecular DNA damage into the cellular DNA and was also found to increase the effect of radiation in these cells $[39,40]$. The studies on the antineoplastic action of berberine on the various stages of tumor development in vivo are lacking. This stimulated us to investigate the antineoplastic activity of $10 \mathrm{mg} / \mathrm{kg} \mathrm{b}$. wt. berberine in mice transplanted with Ehrlich ascites carcinoma on various stages of tumor progression.

\section{Materials and Methods}

\section{Drugs and chemicals}

Berberine chloride (BCL), thiobarbituric acid, trichloroacetic acid, 5,5-dithio2-nitrobenzoic acid (DTNB), glutathione reduced, and tetraethoxypropane were purchased from Sigma Chemical Co. St. Louis, USA, whereas other routine chemicals were procured from Ranbaxy Fine Chemicals, Mumbai, India. Cyclophosphamide was supplied by Biochem Pharmaceutical Industries, Mumbai, India.

\section{Animal care and handling}

The animal care and handling were undertaken according to the guidelines of World Health Organization, Geneva, Switzerland and the INSA (Indian National Science Academy, New Delhi). Female Swiss albino mice aged eight to ten-weeks and weighing 30 to $36 \mathrm{~g}$ were culled from an inbred colony maintained under the controlled conditions of temperature $\left(23 \pm 2{ }^{\circ} \mathrm{C}\right)$, humidity $(50 \pm 5 \%)$ and 12 hours of light and dark cycle, respectively. The animals were allowed free access to sterile food and water. Usually four animal were housed in a sterile polypropylene cage containing sterile paddy husk (procured locally) as bedding throughout the experiments. The study was approved by the institutional animal ethical committee.

\section{Tumor model}

Ehrlich ascites carcinoma (EAC) was procured from the Cancer Research Institute (ACTREC), Mumbai, India. The EAC was propagated and maintained by serial intraperitoneal transplantation of $10^{6}$ viable EAC cells in female mice in an aseptic environment. The day of tumor inoculation was designated as day 0 .

\section{Preparation of drug and mode of administration}

Cyclophosphamide (CPA) was dissolved in sterile physiological saline (SPS), whereas berberine chloride was dissolved in hot double distilled water. The SPS, CPA or BCL were administered intraperitoneally unless otherwise stated.

\section{Experimental}

The antineoplastic activity of BCL was determined by dividing the EAC transplanted mice into the following groups:

a) SPS group: The animals of this group received 0.3 to $0.36 \mathrm{ml}$ of sterile physiological saline (SPS).

b) CPA group: This group of animals received $25 \mathrm{mg} / \mathrm{kg}$ b. wt. of CPA once daily for nine consecutive days and served as concurrent positive control [24].

c) BCL group: The animals of this group were administered with a single dose of $10 \mathrm{mg} / \mathrm{kg}$ BCL once daily, for nine consecutive days [24].

\section{Anticancer activity determination}

A separate experiment was carried out to evaluate the antineoplastic action of BCL, where grouping and other conditions were exactly similar to that described above, except that the animals of CPA and BCA groups were administered with these drugs after 1, 3, 6, 9, 12 and 15 days of tumor transplantation and for reasons of clarity these days have been arbitrarily designated as stage I, II, III, IV, V and VI, respectively.

The animals of all the groups were monitored regularly for alteration in body weight, signs of toxicity and mortality. The weight of animals was recorded every third day up to 30 days after tumor inoculation in all the groups. A 33\% of drug related deaths or a weight loss of $5 \mathrm{~g}$ per mouse was considered as an index of toxicity [41]. The animal survival was monitored daily up to 120 days, since the survival of animals up to 120 days is roughly equivalent to 5 years survival in man [42]. The tumor response 
was assessed on the basis of median survival time and tumor free survival. The median survival time (MST), and the average survival time (AST) were calculated from the animals dying within 120 days and those surviving 120 days were excluded from it.

The MST and AST were calculated as follows:

MST=First death + last death in the group /2.

AST=Sum of animal death on different days/Number of animals.

The increase in median life span (\% IMLS) and increase in average life span (\% IALS) were also calculated using the following formulae:

IMLS=MST of treated mice - MST of control X100/ MST of control.

IALS=AST of treated mice - AST of control X100/AST of control.

\section{Biochemical analyses}

A separate experiment was performed to estimate glutathione and lipid peroxidation in the tumor cells. The grouping and other condition were essentially similar to that described in experimental section except that the animals were inoculated with EAC cells and the tumor was allowed to grow for six days so as to get a reasonable volume for aspiration of cells. On seventh day, the tumor bearing animals were administered only once with SPS or CPA or BCL as the case may be.

Four animals from each group were sacrificed at $0,1.5,3,6,9$, $12,15,18$ or $24 \mathrm{~h}$ after the BCL or CPA administration. The tumor cells were aspirated in aseptic condition and were washed with Results

Table 1: Antineoplastic activity of $10 \mathrm{mg} / \mathrm{kg} \mathrm{BCL}$ in mice transplanted with Ehrlich ascites carcinoma.

\begin{tabular}{|c|c|c|c|c|c|c|c|c|}
\hline \multirow{2}{*}{ Treatment } & \multicolumn{4}{|c|}{ Survival } & \multicolumn{4}{|c|}{ Percent Survival (day) } \\
\hline & MST & IMLS & AST & IALS & 30 & 60 & 90 & 120 \\
\hline SPS & 19 & & 18 & - & 0 & 0 & 0 & 0 \\
\hline $\mathrm{BCl} \mathrm{I}$ & 35.5 & 86.8 & 35.2 & 95.5 & $30 c$ & 0 & 0 & 0 \\
\hline CPA 1 & 29 & 57.9 & 28 & 55.8 & 16.7 & 0 & 0 & 0 \\
\hline $\mathrm{BCl} \mathrm{II}$ & 37 & 84.7 & 33.7 & 87.2 & $58.3 \mathrm{~b}$ & 0 & 0 & 0 \\
\hline CPA II & 26.5 & 39.5 & 26.3 & 46.6 & 8.3 & 0 & 0 & 0 \\
\hline $\mathrm{BCl}$ III & 33 & 73.7 & 32.1 & 78.3 & $33.3 \mathrm{c}$ & 0 & 0 & 0 \\
\hline CPA III & 24 & 26.3 & 23.1 & 28.5 & 0 & 0 & 0 & 0 \\
\hline $\mathrm{BCl} \mathrm{IV}$ & 29.2 & 31.6 & 23.2 & 28.9 & 18 & 0 & 0 & 0 \\
\hline CPA IV & 21.5 & 13 & 21.1 & 17.4 & 0 & 0 & 0 & 0 \\
\hline $\mathrm{BCl} \mathrm{V}$ & 21.5 & 13.1 & 20.3 & 11.3 & 0 & 0 & 0 & 0 \\
\hline CPA V & 19 & - & 18.9 & 5.3 & 0 & 0 & 0 & 0 \\
\hline $\mathrm{BCl} \mathrm{VI}$ & 19 & - & 18.9 & 5.0 & 0 & 0 & 0 & 0 \\
\hline CPA VI & 18.5 & - & 18.2 & 1.6 & 0 & 0 & 0 & 0 \\
\hline
\end{tabular}

$a=p<0.0001 ; b=p<0.001 ; c=p<0.002 ; d=p<0.05$ (when compared with SPS)

SPS: Sterile Physiological Saline; CPA: Cyclophosphamide; BCL: Berberine Chloride

SPS thrice. The cells were counted under an inverted microscope (Labovert microscope, Ernst Leitz, Wetzlar GmbH, Germany) and 1 $10^{6}$ cells were sonicated (Virsonic, Virtis, NY, USA) and processed follows:

Glutathione (GSH): GSH concentration was measured by the method of Moron et al. [43]. Briefly, proteins were precipitated by $25 \%$ TCA, centrifuged and the supernatant was collected. The supernatant was mixed with $0.2 \mathrm{M}$ sodium phosphate buffer $\mathrm{pH}$ 8.0 and $0.06 \mathrm{mM}$ DTNB and incubated for 10 minutes at room temperature. The absorbance of the sample/s was read against the blank at $412 \mathrm{~nm}$ in a UV-Visible double beam spectrophotometer (Shimadzu UV-260, Shimadzu Corporation, Tokyo, Japan) and the GSH concentration was calculated from the standard curve.

Lipid peroxidation (LOO): LOO was measured by the method of Beuege \& Aust [44]. Briefly, the homogenate was mixed with TCA-TBA-HCl and heated for $15 \mathrm{~min}$ in a boiling water bath. After centrifugation the absorbance was recorded at $535 \mathrm{~nm}$ using a UV-Visible double beam spectrophotometer. The lipid eroxidation has been expressed as TBARS in nmol per $10^{6}$ cells. concentration of LOO in the sample was determined against

Statistical analyses: The statistical significance between the treatments was determined using the " $\mathrm{Z}$ " test for the survival studies [45], whereas the student's't' test was used for the biochemical estimations. A p value of $<0.05$ was considered statistically significant. All the data are expressed as mean \pm SEM (standard error of the mean). 


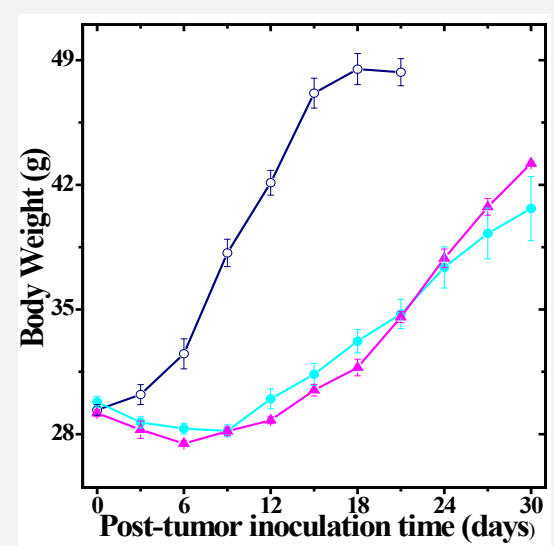

Figure 1: Effect of $10 \mathrm{mg} / \mathrm{kg}$ of berberine chloride $(B C L)$ on the body weights of mice transplanted with Ehrlich ascites carcinoma. Open circles: Sterile Physiological Saline; Closed circles Cyclophosphamide and Triangle: Berberine chloride.

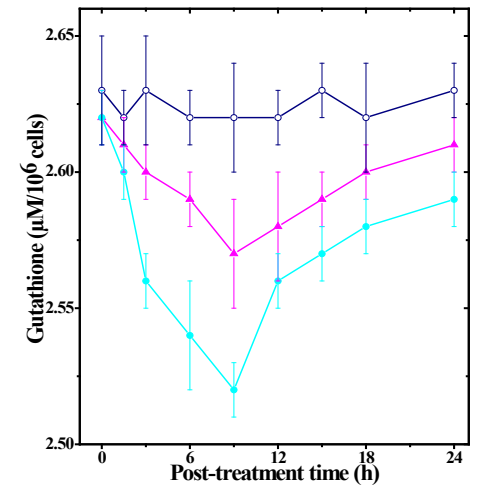

Figure 2: Alteration in the glutathione concentrations in mice bearing Ehrlich ascites carcinoma treated with $10 \mathrm{mg} / \mathrm{kg}$ body weight of berberine. Open circles: Sterile Physiological Saline; Closed circles Cyclophosphamide and Triangle: Berberine chloride.

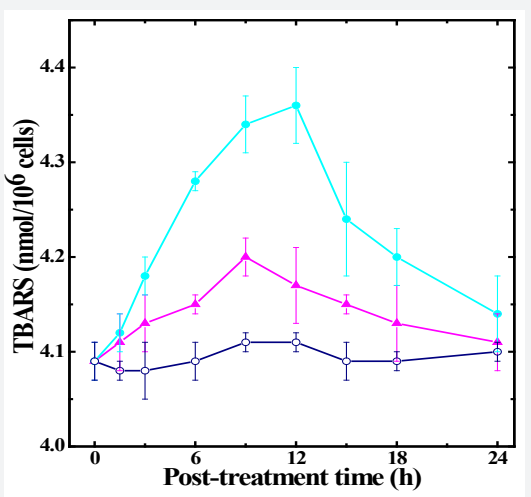

Figure 3: Alteration in the lipid peroxidation in mice bearing Ehrlich ascites carcinoma treated with $10 \mathrm{mg} / \mathrm{kg}$ body weight of berberine. Open circles: Sterile Physiological Saline; Closed circles Cyclophosphamide and Triangle: Berberine chloride.

The results of anticancer activity and biochemical assays are presented in Table 1 and Figure 1, 2 \& 3 as mean \pm SEM.

\section{Anticancer activity determination}

The anticancer activity of BCL was determined by injecting $10 \mathrm{mg} / \mathrm{kg}$ BCL, which was found to be the optimum dose for antineoplastic action [24]. The mice transplanted with EAC tumor did not show any regression until the end of the experiment where all the animals receiving SPS died within-18-19 days (Table 1). The stage specific evaluation of the anticancer activity of BCL was carried out in tumor bearing animals on 1, 3, 6, 9, 12 or 15 days, (stages I, II, III, IV, V and VI, respectively) by administering a single dose of $10 \mathrm{mg} / \mathrm{kg}$ BCL once daily or $25 \mathrm{mg} / \mathrm{kg}$ CPA for nine days, consecutively at stages I, II, III, IV, V or VI. The administration of $25 \mathrm{mg} / \mathrm{kg}$ CPA exerted a significant anticancer activity only when administered in the early stages of tumor development, which is validated by the body weight changes (Figure 1). None of the animals treated with CPA at various stages of tumor development survived beyond 30 days post-tumor cell inoculation (Table 1).

The survival of EAC mice declined in a stage specific manner. The MST for the tumor bearing animal that received CPA at stages I, II, III, IV, V and VI was approximately 29, 26, 24, 21, 19 and 18 days, respectively (Table 1), while AST was approximately 29, 26, 24, 21, 19 and 18 for stage I, II, III, IV, V and VI, respectively. An approximate IMLS, of 58, 39, 26 and 13\% was observed for stages I, II, III and IV, respectively. The administration of CPA at the end stages (i.e. V and VI) proved ineffective in increasing the IMLS. The IALS also decreased in a stage specific manner in the CPA group and it was approximately $56,47,28,17,5$ and $1.6 \%$, for stage I, II, III, IV, V and VI, respectively (Table 1).

The treatment of mice with $10 \mathrm{mg} / \mathrm{kg}$ BCL at stages I, II, III, IV or $\mathrm{V}$ resulted in an increase in the MST approximately up to $35,37,33,29$ and 21 days, whereas administration of BCL raised the AST up to 35, 34, 32, 23 and 20 days, respectively (Table 1). The IMLS and IALS also increased after BCL treatment depending on the stage of the tumor at which the drug was administered. The IMLS and IALS declined depending on the treatment stage and the lowest values were observed for stage V. The IMLS of approximately 87, 85, 74, 32 and $13 \%$ and the IALS of 95, 87, 78, 29 and $11 \%$ were recorded for stage I, II, III, IV and V, respectively after $10 \mathrm{mg} / \mathrm{kg}$ BCL treatment when compared to CPA treatment (Table 1). The stage specific evaluation showed that BCL was effective up to stage IV and a maximum effect was observed for stage II, where approximately 58\% animals survived until 30 days. However no tumor free survivors could be observed beyond 30 days post tumor inoculation (Figure 1). Despite this fact the BCL treatment was more effective than CPA, the positive control as the number of survivors was higher than the CPA group (Table 1).

\section{Biochemical estimations}

Glutathione (GSH): The GSH concentration remained unaltered with time in EAC mice treated with SPS (Figure 2). The administration of CPA or BCL into EAC mice caused a time dependent decline in the GSH concentration in EAC cells till a nadir was reached at $9 \mathrm{~h}$ post-treatment. A further increase in the assay time caused an elevation in GSH contents at $12 \mathrm{~h}$ post-treatment, which continued to rise until $18 \mathrm{~h}$ post-treatment thereafter a steady state was reached (Figure 2). The GSH concentration 
was marginally higher in the BCL group when compared to CPA treatment (Figure 2). Despite the fact that CPA and BCL treatment alleviated GSH concentration the differences were not statistically significant.

Lipid peroxidation (LOO): The lipid peroxidation remained unaltered with time in EAC mice treated with SPS (Figure 3). Treatment of EAC mice with CPA or BCL caused a time dependent increase in the LOO of tumor cells until a peak was reached at 9 and $12 \mathrm{~h}$ post-treatment for BCL and CPA treatments, respectively. This increase in LOO was statistically significant $(p<0.01)$. A further increase in the assay time caused a decline in $\mathrm{LOO}$ at $15 \mathrm{~h}$ posttreatment, however the LOO was significantly $(\mathrm{P}<0.05)$ higher in the CPA treated group, when compared to the SPS treatment. Thereafter a steady state was reached (Figure 3). BCL treatment brought the LOO level to almost SPS level by $24 \mathrm{~h}$ post treatment (Figure 3).

\section{Discussion}

Humans have always relied on nature for survival since ancient times and it has been our main source of food, protection, clothing, transportation and medicines [46,47]. Natural products have been an important source of several medicines including chemotherapeutic agents $[12,48]$. Plant-derived compounds, in particular have a special place in anticancer therapy. Some of the modern chemotherapeutic agents derived from plants or their semi synthetic counterparts currently available in the market for use in a clinical setting are paclitaxel (Taxol), bisindole alkaloids (vinblastine, vincristine, vinorelbine, vinflunine), podophyllotoxin (etoposide, teniposide, and etoposide phosphate) and camptothecins (irinotecan and topotecan), a natural product precursor for water-soluble derivatives. Apart from these many other new plant derived products have been approved by FDA for the treatment of various cancers [12]. This clearly indicates that natural products will continue to be extremely important as sources of medicinal agents. The natural products have found direct medicinal application as drug entities and many others can serve as chemical models or templates for the design, synthesis, and semisynthesis of novel substances for treating human diseases. Although there are some new approaches to drug discovery, such as combinatorial chemistry and computer-based molecular modeling design, none of them can replace the important role of natural products in drug discovery and development. Therefore, it was desired to screen the antineoplastic activity of berberine in Swiss albino mice transplanted with Ehrlich ascites carcinoma.

Human beings suffering from various neoplastic disorders come for clinical evaluation and treatment in the different stages of tumor development. Therefore, an effective anticancer agent should be able to kill tumor cells efficiently during any stage of the tumor [49]. An effort has been made to screen the antineoplastic activity of $10 \mathrm{mg} / \mathrm{kg} \mathrm{BCL}$ at various stages of tumor development with respect to the efficacy of $25 \mathrm{mg} / \mathrm{kg}$ of CPA. The results from the stage specific evaluation show that both BCL and CPA retarded the increase in body weight gain in EAC mice due to tumor development and increased the survival during the early stages effectively. This may be due to the effective killing of EAC cells during the early stages of tumor development by BCL. Berberine has been shown to have an anticancer effect on mice bearing Ehrlich ascites carcinoma at the dose of $10 \mathrm{mg} / \mathrm{kg} \mathrm{b}$. wt. [24]. A similar effect was observed earlier where 5 and $10 \mathrm{mg} / \mathrm{kg}$ berberine retarded the tumor weight gain in mice transplanted with B16 murine melanoma and it also inhibited the proliferation of these cells in vitro [50]. Berberine has been reported to inhibit cell proliferation and cell survival in HeLa cells in a concentration dependent manner recently $[39,40]$. Likewise, berberine has been also reported to exert cytotoxic effect on Saos-2, MG-63, BC-1, BCBL-1, TY-1, U937, FaDu, SW480, and HT-29 human cells of different tissue origin [51-56]. The berberine was ineffective during mid and late stages of tumor development. The studies of the anticancer activity of natural products at different stages of tumor development are scanty. Echitamine, Alstonia scholaris, and Aphanamixis polystychya have been reported to inhibit EAC growth when administered in different stages of tumor development earlier [49,56,57].

Natural medicines have gained popularity over synthetic drugs in recent years with the belief that they are much safer and have led to the tremendous growth of phytopharmaceutical usage [58]. Increased concentration of GSH in the tumor cells have been reported to make the tumor refractory to treatment, whereas depletion of glutathione has been reported to enhance the cell death and apoptosis of the tumor cells along with the loss of essential sulfhydryl groups that result in an alteration of the calcium homeostasis and eventually loss of cell viability $[59,60]$. The lipid peroxidation is another important event related to cell death and has been reported to cause severe impairment of membrane function through increased membrane permeability and membrane protein oxidation and eventually cell death by damaging the important cellular macromolecules like DNA, RNA and proteins $[61,62]$. A similar effect has been observed in the present study where BCL has reduced GSH concentration and elevated the LOO considerably. The increase and reduction in LOO and GSH respectively by BCL may have damaged the DNA of EAC cells thereby bringing effective tumor cell kill. The changes in the membrane fluidity coupled with the damage to DNA by BCL may have been responsible for the killing of tumor cells and prolongation of life span in EAC mice during early stages.

The exact mechanism of cell killing by berberine in the present study is not very clear. It is possible that berberine may have utilized mutiple pathways to kill EAC tumor cells in mice. The berberine may interact with DNA and RNA forming compex with them [63]. The triggering of DNA damage by bereberine treatment may be one of the imoprtant causes of cell death that subsequently increased the life span of tumor bearing animals. Our erlier studies have shown that berberine causes molcular DNA damage in HeLa cells [39,40]. The other mechanism may be the inhibition of topoisomerase II by BCL, which may have stabilized the transient DNA double strand breaks leading to cell death. 
Berberine has been reported to inhibit topoisomerase-II [26]. The presence of berberine may have suppressed the activation of nuclear factor kappa B (NF- $\mathrm{KB}$ ) invovled in providing survival advantage to cancer cells [64]. This would have led to the inhbition of antiapototic proteins and activation of apoptotic machinery by upregulating p53 expression and inhibiting the expression of Bcl2 and COX-II cauisng tumor cell death $[63,65]$. The berberine may have triggered apoptosis in tumor cells by activating caspase 3 , 7, 8 and 9 along with FasL and TNF-related apoptosis-inducing ligands, and proapoptotic proteins including Bax, Bad, and Apaf1 follwed by the suppression the anti-apoptotic factors, such as Bcl-2 and Bcl-xL as reported earlier [54]. Berberine has been also reported to inhibit EGFR, AKT, MAPK, and STAT3 which play a crucial role in cell proliferation [63,65]. Cell cycle arrest could be another mechanism of retardation in cell proliferation as berberine has been found to arrest the cells in G1 and G2 phase and suprress cylcin expression [66]. The suppression of Nrf2 may have also contributed in the cell killing effect of berberine as it enhanced LOO and reduced GSH in the present study.

\section{Conclusion}

Berberine has killed EAC cells resulting in the increased survival of tumor bearing mice treated with $10 \mathrm{mg} / \mathrm{kg}$ b. wt. BCL. It was most effective when it was administered on day 2 after tumor transplantation. Berberine significantly increased LOO and reduced the GSH contents. Berberine may have killed the tumor cells by inducing molecular DNA damage or forming complexes with DNA and RNA. The inhibition of topoisomerase II, NF- $\kappa B$, EGFR, AKT, MAPK, STAT3, Bcl-2 and Bcl-xL may have played important role at molecular level to bring the death of EAC cells after berberine treatment. Berberine may have also activated caspase 3, 7, 8 and 9 along with FasL, Bax, Bad, and Apaf-1 causing apoptotic death of tumor cells.

\section{Acknowledgement}

This work was carried out under the grants from the Council of Scientific and Industrial Research, and Indian Council of Medical Research, Govt. of India, New Delhi, India.

\section{Referances}

1. Parascondola J (2008) The theoretical basis of Paul Ehrlich's chemotherapy. J History Med 36(1): 19-43.

2. DeVita VT, Chu E (2008) A History of Cancer Chemotherapy. Cancer Res 68(21): 8643-8653.

3. Bouwman P, Jonker J (2012) The effects of deregulated DNA damage signalling on cancer chemotherapy response and resistance. Nature Revi Cancer 12(9): 587-598.

4. Woods D, Turchi J (2013) Chemotherapy induced DNA damage response: Convergence of drugs and pathways. Cancer Biol Ther 14(5): 379-389.

5. Morton LM, Swerdlow AJ, Schaapveld M, Ramadan S, Hodgson DC, et al (2014) Current knowledge and future research directions in treatmentrelated second primary malignancies. EJC Suppl 12(1): 5-17.

6. Siegel RL, Miller KD, Jemal A (2016) Cancer Statistics, 2016. CA Cancer J Clin 66(1): 7-30.
7. Pedersen B, Koktved DP, Nielsen LL (2013) Living with side effects from cancer treatment -a challenge to target information. Scand J Caring Sci 27(3): 715-723.

8. Iwamoto $\mathrm{T}$ (2013) Clinical application of drug delivery cystems in cancer chemotherapy: review of the efficacy and side effects of approved drugs. Biol Pharm Bull 36(5): 715-718.

9. Zhang X, Chen WW, Huang WJ (2017) Chemotherapy-induced peripheral neuropathy. Biomed Rep 6: 267-271.

10. Baguley BC (2002) A brief history of cancer chemotherapy. In: Anticancer Drug Development. Academic Press, New York, USA, p. 1-11.

11. Greenlee H, Neugut AI, Falci L, Hillyer GC, Buono D, et al. (2016) Association between complementary and alternative medicine use and breast cancer chemotherapy initiation: the Breast Cancer Quality of Care (BQUAL) study. JAMA Oncol 2(9): 1170-1176.

12. Kinghorn AD, De Blanco EJC, Lucas DM, Rakotondraibe HL, Orjala J, et al. (2016) Discovery of anticancer agents of diverse natural origin. Anticancer Res 36(11): 5623-5637.

13. Wargovich MJ, Woods C, Hollis DM, Zander ME (2001) Herbals, cancer prevention and health. J Nutr 131(11): 3034S-3036S

14. Huebner J, Marienfeld S, Abbenhardt C, Ulrich C, Muenstedt K, et al. (2014) Counseling patients on cancer diets: a review of the literature and recommendations for clinical practice. Anticancer Res 34(1): 3948.

15. Jagetia GC, Rao SK (2017) Berberinechloride, an isoquinoline alkaloid induces cytotoxicity in cultured HeLa Cells. Adv Biotechnol Biochem 2017: J120.

16. Kuo CL, Chou CC, Yung BY (1995) Berberine complexes with DNA in the berberine-induced apoptosis in human leukemic HL-60 cells. Cancer Lett 93(2): 193-200.

17. Yang IW, Chou CC, Yung BYM (1996) Dose-dependent effects of berberine on cell cycle pause and apoptosis if Balb/c 3T3 cells. NaunynSchmiedeberg's Arch Pharmacol 354(2): 102-108.

18. Williamson EM (2001) Synergy and other interactions in phytomedicines. Phytomedicine 8(5): 401-409.

19. Singh A, Duggal S, Kaur N, Singh J (2010) Berberine: Alkaloid with wide spectrum of pharmacological activities. J Nat Prod 3(2010): 64-75.

20. Nadkarni KM, Nadkarni AK (1976) Indian Materia Medica, Vol 1 ( $3^{\text {rd }}$ edn.), Popular Prakasan Pvt Ltd, Mumbai, India.

21. Zhao THF, Wang X, Rimando AM, Che C (1991) Folkloric medicinal plants: Tinospora sagittata var. cravaniana and Mahonia bealei. Planta Med 57(5): 505.

22. Chopra RN, Nayar SL, Chopra IC (1996) Glossary of Indian Medicinal Plants. Publications \& Information Directorate, Govt. India, New Delhi.

23. Anis KV, Rajeshkumar NV, Kuttan R (2001) Inhibition of chemical carcinogenesis by berberine in rats and mice. J Pharm Pharmacol 53(5): 763-768.

24. Jagetia GC, Baliga MS (2004) Effect of Alstonia scholaris in enhancing the anticancer activity of berberine in the Ehrlich ascites carcinoma bearing mice. J Med Food 7(2): 235-244.

25. Choi MS, Oh JH, Kim SM, Jung HY, Yoo HS, et al. (2009) Berberine inhibits p53-dependent cell growth through induction of apoptosis of prostate cancer cells. Int J Oncol 34(5): 1221-1230.

26. Ortiz LM, Lombardi P, Tillhon M, Scovassi AI (2014) Berberine, an epiphany against cancer. Molecules 19(8): 12349-12367.

27. De Oliveira JS, Abdalla FH, Dornelles GL, Adefegha SA, Palma TV, et al. (2016) Berberine protects against memory impairment and anxiogenic-like behavior in rats submitted to sporadic Alzheimer's- 
like dementia: Involvement of acetylcholinesterase and cell death Neurotoxicology 57: 241-250.

28. Neto FR (1993) Electropharmacological effects of berberine on canine cardiac Purkinje fibres and ventricular muscle and atrial muscle of the rabbit. Br J Pharmacol 108(2): 534-537.

29. Zeng XH, Zeng XJ, Li YY (2003) Efficacy and safety of berberine for congestive heart failure secondary to ischemic or idiopathic dilated cardiomyopathy. Am J Cardiol 92(2): 173-176.

30. Yin J, Xing H, Ye J (2008) Efficacy of berberine in patients with type 2 diabetes mellitus. Metabolism 57(5): 712-717.

31. Zhang H, Wei J, Xue R, Wu JD, Zhao W, et al. (2010) Berberine lowers blood glucose in type 2 diabetes mellitus patients through increasing insulin receptor expression. Metabolism 59(2): 285-292.

32. Lan J, Zhao Y, Dong F, Yan Z, Zheng W, et al. (2015) Meta-analysis of the effect and safety of berberine in the treatment of type 2 diabetes mellitus, hyperlipemia and hypertension. J Ethnopharmacol 161: 6981.

33. Hu Y, Ehli EA, Kittelsrud J, Ronan PJ, Munger K, et al. (2012) Lipidlowering effect of berberine in human subjects and rats. Phytomedicine 19(10): 861-867.

34. Chang X, Wang Z, Zhang J, Yan H, Bian H, et al. (2016) Lipid profiling of the therapeutic effects of berberine in patients with nonalcoholic fatty liver disease. J Transl Med 14: 266

35. Di Pierro F, Putignano P, Ferrara T, Raiola C, Rapacioli G, et al. (2016) Retrospective analysis of the effects of a highly standardized mixture of Berberis aristata, Silybum marianum, and monacolins K and KA in patients with dyslipidemia. Clin Pharmacol 9: 1-7.

36. Huang M, Chen S, Liang Y, Guo Y (2016) The role of berberine in the multi-target treatment of senile dementia. Curr Top Med Chem 16(8): 867-873.

37. Koppen LM, Whitaker A, Rosene A, Beckett RD (2017) Efficacy of berberine alone and in combination for the treatment of hyperlipidemia: A systematic review. J Evid Compl Altern Med 1-13.

38. Yang Y, Wang Q, Xie M, Liu P, Qi X, et al. (2017) Berberine exerts an anti-inflammatory role in ocular Behcet's disease. Mol Med Rep 15(1): 97-102.

39. Jagetia GC, Rao SK (2015) Isoquinoline alkaloid berberine exerts its antineoplastic activity by inducing molecular DNA damage in HeLa cells: A comet assay study. Biology and Medicine 7(1): 223.

40. Jagetia GC, Rao SK (2016) The isoquinoline alkaloid berberine augments radiation effect by enhancing the DNA damage at molecular level in HeLa cells irradiated with various doses of $\gamma$-radiation: Correlation between DNA damage and clonogenicity. J Mol Genet Med 10: 235

41. Geran RI, Greenberg NH, Mac Donald MM, Schumacher AM, Abbott B (1972) Protocols for screening chemical agents and natural products against animal tumors and other biological systems. Cancer Chemother Rep 3(2): 1-103.

42. Nias AHW (1990) Radiation Biology. In: Sikora K \& Halnan KE (eds.), Treatment of cancer. Chapman and Hall Medical, London, UK, p. 53-75.

43. Moron MS, Depierre JW, Mannervik B (1979) Levels of glutathione, glutathione reductase and glutathione $\mathrm{S}$-transferase activities in rat lung and liver. Biochim Biophys Acta 582(1): 67-78.

44. Buege JA, Aust SD (1978) Microsomal lipid peroxidation. Methods Enzymol 52: 302-310.

45. Abramowitz M, Stegun IA (1972) Handbook of Mathematical Functions. Library of Congress Catalog Card Number 65-12253. Dover Publications, Inc. New York, p. 925.
46. Farnsworth NR, Akerele O, Bingel AS, Soejarto DD, Guo Z (1985) Medicinal plants in therapy. Bull World Health Organ 63(6): 965-981.

47. Cragg GM, Newman DJ, Snader KM (1997) Natural products in drug discovery and development. J Nat Prod 60(1): 52-60.

48. Newman DJ, Cragg GM (2016) Natural products as sources of new drugs from 1981 to 2014. J Nat Prod 79(3): 629-661.

49. Jagetia GC, Baliga MS (2016) Preclinical Evaluation of the Anticancer Activity of Hydroalcoholic Stem Bark Extract of Alstonia scholaris in Ehrlich Ascites Carcinoma Transplanted in the Swiss Albino Mice. J Alt Med Res 2(2): 115.

50. Letašiová S, Jantová, S, Múčková M, Theiszová, M (2005) Antiproliferative activity of berberine in vitro and in vivo. Biomed Pap Med Fac Univ Palacky Olomouc Czech Repub 149(2): 461-463.

51. Letasiová S, Jantová S, Cipák L, Múcková M (2006) Berberineantiproliferative activity in vitro and induction of apoptosis/necrosis of the U937 and B16 cells. Cancer lett 239(2): 254-262.

52. Goto H, Kariya R, Shimamoto M, Kudo E, Taura M, et al. (2012) Antitumor effect of berberine against primary effusion lymphoma via inhibition of NF- $\kappa B$ pathway. Cancer Sci 103(4): 775-781.

53. Cai Y, Xia Q, Luo R, Huang P, Sun Y, et al. (2014) Berberine inhibits the growth of human colorectal adenocarcinoma in vitro and in vivo. J Natural Med 68(1): 53-62.

54. Seo YS, Yim MJ, Kim BH, Kang KR, Lee SY, et al. (2015) Berberineinduced anticancer activities in FaDu head and neck squamous cell carcinoma cells. Oncol Rep 34(6): 3025-3034.

55. Jin H, Jin X, Cao B, Wang W (2017) Berberine affects osteosarcoma via downregulating the caspase- $1 / \mathrm{IL}-1 \beta$ signaling axis. Oncol Rep 37(2): 729-736.

56. Jagetia GC, Baliga MS (2003) Modulation of antineoplastic activity of cyclophosphamide by Alstonia scholaris in the Ehrlich ascites carcinoma-bearing mice. J Exp Ther Oncol 3(5): 272-282.

57. Jagetia GC, Venkatesha VA (2012) Preclinical determination of the anticancer activity of rohituka (Aphanamixis polystachya) in ehrlich ascites tumor-bearing mice. Med Arom Plant Sci Biotechnol 6(Special Issue 2): 42-51.

58. Shantabi L, Jagetia GC, Vabeiryureilai M, Lalrinzuali K (2014) Phytochemical screening of certain medicinal plants of Mizoram, India and their folklore Use. J Biodiver Bioprospect Develop 1: 136.

59. Axelson K, Mannervik B (1983) An essential role of cytosolic thioltransferase in protection of pyruvate kinase from rabbit liver against oxidative inactivation. FEBS Lett 152: 114-118.

60. Neal R, Matthews RH, Lutz P, Ercal N (2003) Antioxidant role of $\mathrm{N}$-acetyl cysteine isomers following high dose irradiation. Free Rad Biol Med 34(6): 689-695.

61. Bartsch H, Nair J (2002) Potential role of lipid peroxidation derived DNA damage in human colon carcinogenesis: studies on exocyclic base adducts as stable oxidative stress markers. Cancer Detect Prev 26(4): 308-312.

62. Marnett LJ (2002) Oxy radicals, lipid peroxidation and DNA damage. Toxicology 181-182: 219-222.

63. Sun Y, Xun K, Wang Y, Chen X (2009) A systematic review of the anticancer properties of berberine, a natural product from Chinese herbs. Anticancer Drugs 20(9): 757-769.

64. Lu T, Stark GR (2015) NF-кB: Regulation by Methylation. Cancer Res 75(18): 3692-3695.

65. Wang J, Yang S, Cai X, Dong J, Chen Z, et al. (2016) Berberine inhibits EGFR signaling and enhances the antitumor effects of EGFR inhibitors in gastric cancer. Oncotarget 7(46): 76076-76086. 
66. Tan W, Lu J, Huang M, Li Y, Chen M, et al. (2011) Anti-cancer natural products isolated from Chinese medicinal herbs. Chinese Med 6(1): 27.

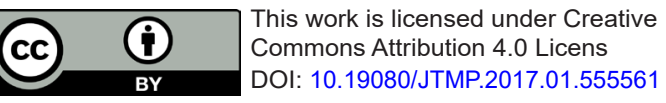

\begin{tabular}{|l|}
\hline \multicolumn{1}{|c|}{ Your next submission with Juniper Publishers } \\
will reach you the below assets \\
- Quality Editorial service \\
- Swift Peer Review \\
- Reprints availability \\
- E-prints Service \\
- Manuscript Podcast for convenient understanding \\
- Global attainment for your research \\
- Manuscript accessibility in different formats \\
( Pdf, E-pub, Full Text, Audio) \\
- Unceasing customer service \\
Track the below URL for one-step submission \\
https://juniperpublishers.com/online-submission.php \\
\hline
\end{tabular}

